som eksempelvis en i udpræget grad idealistisk tradition eller bevægelse.

Middelalderhistorikeren Sverre

Bagge giver med sit bidrag et spændende indblik i den gensidige krydsbefrugtning som kan finde sted, hvis historikeren og idéhistorikeren vælger samarbejdet frem for den lidet produktive skyttegravskrig, som ellers tit har præget forholdet mellem de to respektive fag. Det gælder med andre ord om at komme hinsides historikerens traditionelle hang til at operere med materialistiske forklaringsmodeller og et naiv-positivistisk erkendelsesideal samtidig med, at man prøver at undgå idéhistorikerens lige så fejlagtige trang til idealisme, historiefilosofiske eskapader og åndsaristokratisme. Begge dele fører nemlig til en reduktiv og dårlig historieskrivning, som ingen - hverken historikeren eller idéhistorikeren - kan være tjent med.

Bogens afsluttende artikel - forfattet af bogens anden, kvindelige og ikke-norske bidragyder Victoria Höög handler om de udfordringer, som et klassisk, humanistisk dannelsesfag som idéhistorie nødvendigvis må stå overfor $i$ et intellektuelt klima, hvor begreber som kompetencer og livslang læring langsomt stjæler billedet. Höög argumenterer for, at idéhistorie må profilere sit kritiske og aktualiserende potentiale og dermed medvirke til at rehabilitere humanioras centrale betydning for samfundets dannelse. En dannelse, der er med til at skabe referencerammer for den kritiske debat, som er så vital og vigtig for alle demokratiske samfund, der ønsker at vedblive sådanne. Men også en dannelse, der er med til at give os en fornemmelse af medborgerskab. En fornemmelse, som vi i den grad synes at mangle for indeværende.

Alt taget $\mathrm{i}$ betragtning - jeg må anbefale eventuelle æstetikere blandt Slagmarks læsere at se bort fra bogens gyselige forside! - er der tale om en solid udgivelse, som hermed anbefales alle, der måtte interessere sig for idéhistorie som fagligt felt - før, nu og i fremtiden.

Paw Hedegaard Amdisen

\section{Vor tids psykiatri}

Einar Kringlen: Psykiatriens samtidshistorie. Kobenhavn, Hans Reitzels Forlag, 2003, 372 sider, 375 kroner.

For ganske få år siden forsøgte den slovenske filosof Slavoj Zizek at drage en analogi mellem plottet i George Lucas' Star Wars-film og George W. Bush's bekæmpelse af terrorismen. Idéen var i al sin enkle kompleksitet at vise, hvordan de gode, i deres bestræbelse på at bekæmpe ondskaben, selv risikerer at blive forvandlet til de onde. Denne banale logik gælder ikke kun for stjernekrigere og levebrødspolitikere men findes $i$ alle menneskelivets forhold, ja selv for de intellektuelle i deres mærkværdige distance fra dette liv og fra troen på, at der egentligt overhovedet findes noget sådant som godt og ondt. Et eksempel er de kritiske analyser, hvormed den franske idéhistoriker 
Michel Foucault forsøgte at udfordre de etablerede institutioner i den moderne velfærdsstat ved at afsløre deres iboende farer. I dag indgår en stor del af Foucaults begrebsapparat i det herskende vidensregime og hans analytiske pointer er enten hengået i glemsel eller blevet indoptaget $i$ institutionernes egen selvforståelse - snarere end at ryste har udfordringen præserveret og styrket det etablerede system.

Sidstnævnte forhold gør sig i et vist omfang også gældende for disputatsen De la folie à l'áge classique - Folie et déraison (Galskabens historie) fra 1961, hvor Foucault fremstiller en Heidegger-inspireret hypotese om, at psykiatriens opståen markerer en tildækning af galskabens væren. På den ene side er værket - sammen med utallige lignede kritiske analyser af psykiatrien fra 1960'erne og 1970'erne - nemlig blevet stuerent, fordi det psykiatriske system i dag indeholder en kritisk refleksion over sine egne historiske skygger. På den anden side er værket endt som noget af et historisk kuriosum, fordi det næsten par excellence skal anfægtes i ethvert nutidigt forsøg på at bedrive seriøs psykiatrihistorie.

Kærligheden for hadet til Foucaults disputats toner ligeledes frem i den internationalt anerkendte norske psykiater Einar Kringlens bog Psykiatriens samtidshistorie, hvor der dog også langes ud til andre sider. Kringlen er en erfaren repræsentant for et system, der gennem tiden er blevet beskyldt for megen råddenskab, men i denne bog optræder han i egne øjne som korsfarer for den gode sag. Hans sigte er imidlertid først og fremmest at missionere $i$ sin egen sundhedsvidenskabelige fagkreds, og bogen opfylder da heller ikke kriterierne for god humanistisk videnskabelighed. Dertil falder Kringlens forsøg på at sætte psykiatriens udvikling ind $i$ en bredere samfunds- og kulturhistorisk kontekst for meget igennem. Bogen indløser ganske enkelt ikke sit eget forehavende i forhold til at belyse de økonomiske, sociale, psykologiske og værdimæssige som generelle faktorer i psykiatriens udviklingshistorie. Det fornemmes således, at disse elementer primært inddrages, hvor de kan fungere som midler i Kringlens korstog med henblik på at underminere modstanderens saglige og faglige status. Lidt typisk for bogens samtid udnævnes hovedskurken til at være psykoanalysen og dens følgesvende - værst er i den forbindelse franskmanden Jacques Lacan, der udråbes til at være en ren humbugmager.

Kringlens bog koncentrerer sig om at fremstille et vue over psykiatriens udvikling efter 2. verdenskrig, og som sådan fungerer den som et udmærket oversigtsværk i forhold til at få et indblik i periodens teorier og praksisser på området. Som middel til at forstå psykiatriens rolle i vores kultur og de samfundsmæssige forhold, der bidrager til at forme dens historie, glimrer bogen imidlertid ved sine mangler og sin alt for ensidige, travesterede og tidstypiske position i forstålsen af kampen mellem de gode og de onde.

Anders Draby Sorensen 